\title{
KINERJA PELAT BETON KOMPOSIT FLOOR DECK TERHADAP LENTUR
}

\author{
M. Fahri Fatharani ${ }^{1}$, Yulianto P. Krisologus ${ }^{2}$ \\ ${ }^{1}$ Jurusan Teknik Sipil, Politeknik Negeri Bandung, Bandung 40012 \\ E-mail:m.fahri.mtri19@polban.ac.id \\ ${ }^{2}$ Jurusan Teknik Sipil, Politeknik Negeri Bandung, Bandung 40012 \\ E-mail : yulianto@polban.ac.id
}

\begin{abstract}
ABSTRAK
Penggunaan floor deck dalam dunia konstruksi berkembang dengan pesat. Salah satu kelebihan yang dimiliki floor deck adalah adanya embossment atau profil yang timbul pada permukaan floor deck hal ini bertujuan untuk mengurangi slip yang terjadi antara beton dengan floor deck. Pada penelitian ini bertujuan untuk mengetahui lendutan, regangan dan slip yang terjadi pada pelat beton komposit akibat pembebanan monotonik. Benda uji yang digunakan dalam penelitian ini berjumlah 3 buah model pelat lantai dengan ukuran $1800 \mathrm{~mm}$ x $500 \mathrm{~mm}$ x $120 \mathrm{~mm}$ dengan mutu beton K-300 serta menggunakan floor deck setebal 0,75 mm nama bahan metal Deck. Pengujian dilakukan dengan skema pembebanan two-point loads dengan kapasitas alat $100 \mathrm{kN}$. Deteksi respons akibat beban dalam pengujian menggunakan potensiometer sebagai pendeteksi lendutan yang terjadi dan strain gauge digunakan untuk mendeteksi regangan yang terjadi pada beton dan floor deck. Analisis yang dilakukan berdasarkan metode Steel Deck Institute C2017. Hasil pengujian menunjukkan bahwa rerata lendutan maksimum yang terjadi sebesar 35 mm pada beban mencapai $33,07 \mathrm{kN}$ dengan slip rerata dari setiap sampel mencapai $24,64 \mathrm{~mm}$. Regangan yang terjadi maksimum terjadi pada tengah bentang untuk regangan beton mencapai 0,044 dan regangan yang terjadi pada floor deck mencapai 649 pada saat beban mencapai $27,8 \mathrm{kN}$.
\end{abstract}

Kata Kunci: Floor Deck, Pelat Beton Komposit, Slip Lendutan

\section{ABSTRACT}

The use of floor decks in the construction world is growing rapidly. One of the advantages of the floor deck is that there is an embossment or profile that arises on the surface of the floor deck, which aims to reduce the slip that occurs between the concrete and the floor deck. This study aims to determine the deflection, strain, and slip that occurs in the composite concrete slab due to monotonic loading. The test objects used in this study amounted to 3 pieces of floor plate models with a size of $1800 \mathrm{~mm} x 500 \mathrm{~mm}$ $x 120 \mathrm{~mm}$ with $\mathrm{K}-300$ concrete quality and using a $0.75 \mathrm{~mm}$ thick floor deck, the name of the metal deck material. Tests were carried out with a two-point loads loading scheme with a tool capacity of $100 \mathrm{kN}$. Detection of the response due to load in testing using a potentiometer to detect the deflection that occurs, and the strain gauge is used to detect the strain that occurs in the concrete and floor deck. The analysis was carried out based on the Steel Deck Institute C-2017 method. The test results show that the maximum mean deflection that occurs is $35 \mathrm{~mm}$ at the load reaching $33.07 \mathrm{kN}$ with the average slip of each sample reaching $24.64 \mathrm{~mm}$. The maximum strain that occurs in the middle of the span for the concrete strain reaches 0.044 and the strain that occurs on the floor deck reaches 649 when the load reaches $27.8 \mathrm{kN}$.

Keywords: Floor Deck, Composite Concrete Slab, End Slip, Deflection.

\section{PENDAHULUAN}

Penggunaan produk lembaran baja gelombang dalam dunia konstruksi berkembang dengan pesat. Penggunaannya sebagai dasar dalam pembuatan elemen struktur khususnya pelat beton komposit menjadi salah satu opsi terbaik dengan kelebihan yang dimiliki lembaran baja gelombang (floor deck) ini. Beberapa kelebihan diantaranya adalah bentuknya yang sederhana sehingga dalam penggunaan tidak memerlukan tenaga ahli khusus, dibentuk sedemikian rupa sehingga memiliki ikatan secara mekanik terhadap beton di atasnya. Pelat baja gelombang dapat berfungsi sebagai pengganti tulangan positif, diberi lapisan tahan karat sehingga mempunyai umur pakai (life time) yang cukup panjang, dan untuk kondisi tertentu dapat berfungsi sekaligus sebagai penutup langitlangit. Oleh karena itu, berdasarkan keuntungan di atas, pelat komposit dapat diterima secara luas baik skala kecil untuk bangunan permukiman maupun digunakan oleh industri. Di sisi lain, beberapa kekurangan dari sistem ini dapat disoroti, seperti: kerentanan 
terhadap kerusakan akibat kebakaran, perhatian yang besar harus diberikan pada ikatan antara beton dan dek baja, dan perlindungan harus diberikan sehubungan dengan kerusakan akibat tingginya beban lokal [1].

Pada dasarnya pelat beton komposit merupakan beton yang dicor di atas floor deck atau lembaran baja bergelombang. Dalam hal ini floor deck dapat menggantikan peran bekisting pada pelat lantai [2]. Pada pelaksanaannya penggunaan wiremesh dilakukan untuk mencegah rangkak dan susut beton pada proses pengeringan [3]. Desain dari lembaran pelat floor deck ini terdapat beberapa tonjolan berpola yang berhubungan langsung dengan beton. Pola ini merupakan embossment yang bertujuan menahan slip yang terjadi antara beton dengan floor deck. Besarnya slip yang terjadi sangat dipengaruhi jumlah, bentuk dan profil embossment [4]. Oleh karena itu, banyak industri yang memproduksi floor deck dengan profil, jumlah dan bentuk dari embossment tersebut.

Lembaran komposit dianggap sebagai salah satu metode penguatan diafragma terbaik. Pengalaman sebelumnya menunjukkan bahwa diafragma jenis ini umumnya memungkinkan ketebalan pelat yang lebih rendah (konsumsi beton), daya dukung beban yang lebih tinggi, dan pengurangan ukuran untuk komponen struktur (kolom, balok, fondasi) [5]. Desain ultimate pada struktur pelat beton bertulang memungkinkan pelat didesain lebih tipis/ramping. Namun dengan pelat tipis permasalahan timbul adalah lendutan yang terjadi pada pelat. Permasalahan semakin nyata ketika ada aktivitas di atas pelat yang menimbulkan beban dinamik pada pelat tersebut, sehingga berakibat pada lendutan yang terjadi. Pada saat beton mengalami keruntuhan akibat tekan maka floor deck berfungsi sebagai penguat tarik seperti fungsi tulangan pada beton bertulang. Gaya geser horizontal dan perilaku lentur pada pelat komposit menjadi penyebab terjadinya debonding antara beton dengan floor deck [5].

Maka dari itu penelitian pelat beton komposit floor deck ini memiliki tujuan untuk mengetahui ketahanan pelat beton komposit floor deck terhadap lendutan, regangan dan slip yang terjadi akibat pembebanan secara monotonik. Melakukan analisa dan studi komparasi hasil uji terhadap syarat dan ketentuan yang berlaku sehingga elemen struktur beton komposit floor deck dapat diaplikasikan pada setiap jenis konstruksi sesuai dengan syarat.

\section{STUDI PUSTAKA}

\section{METODOLOGI}

Bahan aluminium floor deck mempunyai ukuran nominal lebar $100 \mathrm{~cm}$, tebal $0.75 \mathrm{~mm}$ dan panjang $300 \mathrm{~cm}$ dengan tipe floor deck dengan nama metal Deck digunakan sebagai dasar sekaligus sebagai bekisting dari pelat beton komposit. Ukuran floor deck yang digunakan adalah $1800 \mathrm{~mm} \times 500 \mathrm{~mm}$ tebal $0.75 \mathrm{~mm}$.

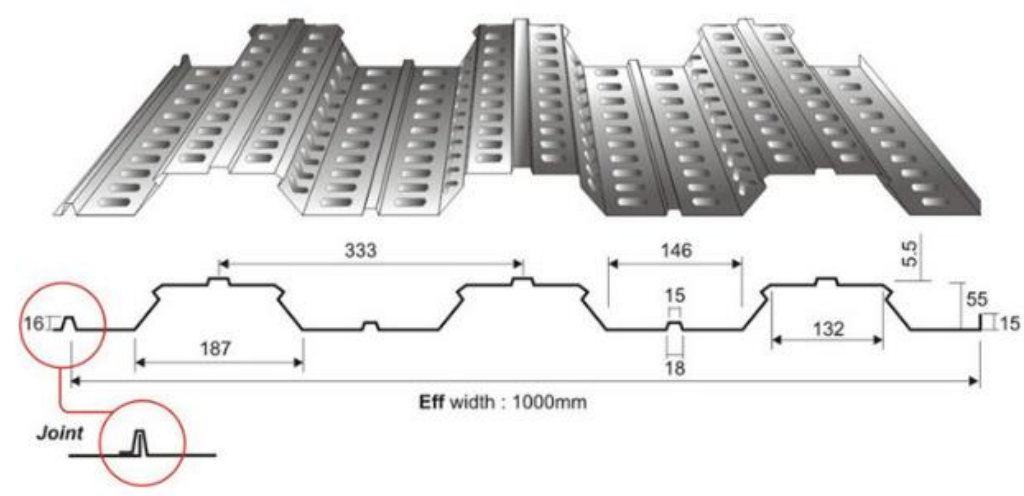

Gambar 1. Profil Floor Deck

Penelitian ini menggunakan metode eksperimental dengan benda uji pelat beton komposit sebanyak 3 buah (FD-1, FD-2, dan FD-3) dengan mutu beton K-300 yang memiliki ukuran $1800 \mathrm{~mm}$ x $500 \mathrm{~mm}$ x $120 \mathrm{~mm}$. Setup pengujian dengan meletakan pelat beton komposit floor deck pada posisi horizontal dan ditumpu pada kedua sisi pendeknya dan pemberian beban two point loads yang berada pada L/3 dari kiri dan kanan dari panjang benda uji dengan kapasitas beban mencapai $100 \mathrm{KN}$ secara monotonik. Pemberian beban dilakukan secara bertahap sampai mencapai beban runtuh.

Pengamatan lendutan dan regangan pada beton dan tulangan dilakukan dengan strain gauge dan potensiometer. Potensiometer diletakan tepat di tengah bentang dan di bawah beban terpusat. Tiga buah strain gauge eksternal dipasang pada beton terletak pada tengah bentang dan pada tumpuan dengan tujuan mengetahui regangan yang terjadi pada daerah lentur beton dan geser beton. Tiga buah strain gauge eksternal dipasang pada bagian bawah pelat tepatnya pada floor deck dengan posisi yang sama seperti pada strain 
gauge beton. Dengan dilakukannya pembebanan pada benda uji, pengujian slip bisa dilakukan dengan cara pemberian beban pada benda uji secara bertahap. Setiap interval beban diukur slipnya dengan LVDT. Pengukuran dilakukan pada salah satu ujung sampel dikarenakan pembebanan pada posisi simetris.

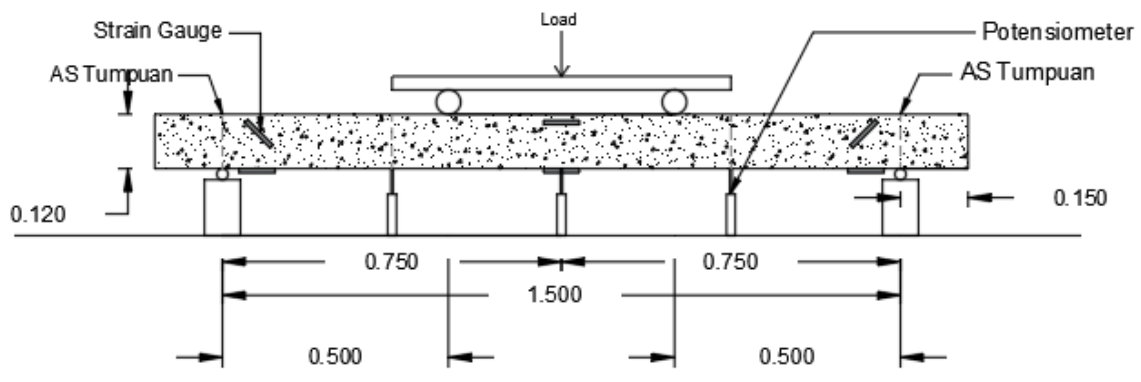

Gambar 2. Setup pengujian pelat beton komposit

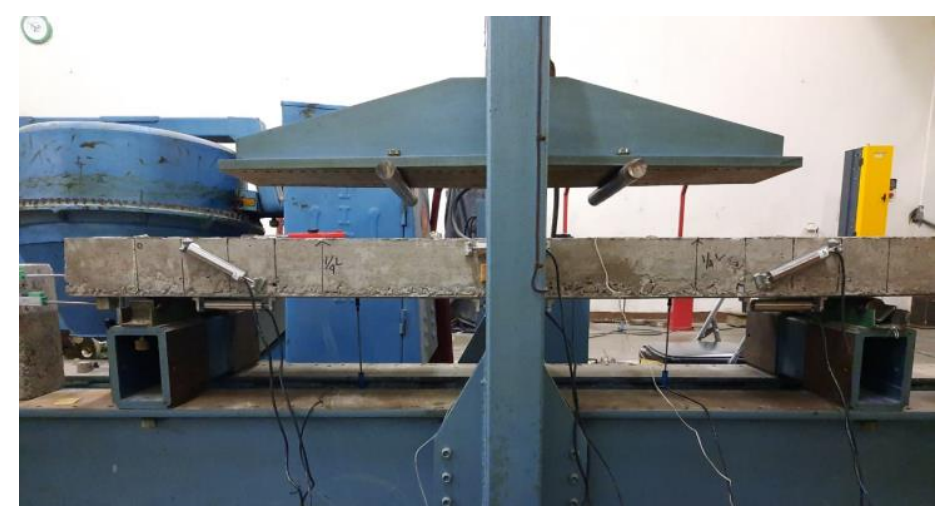

Gambar 3. Pengujian pelat beton komposit

\subsection{Lendutan}

Lendutan dari sebuah pelat komposit beton floor deck dapat dihitung dengan menggunakan nilai rata-rata dari momen inersia pada kondisi cracked dan uncracked [4]. Menghitung nilai lendutan maksimum yang terjadi pada pelat beton komposit memiliki tujuan untuk mempertimbangkan kapasitas alat. Perhitungan lendutan dan nilai rata-rata dari momen inersia menurut American National Standards Institute/Steel Deck Institute C - 2017.

$$
\Delta P=\frac{0.5283 P * 12}{b_{e}} * \frac{L^{3}}{E_{s} * I_{d}}
$$

dengan:

dimana:

$$
I_{d}=\frac{I_{u}+I_{c}}{2}
$$

$\mathrm{I}_{\mathrm{d}} \quad=$ Momen inersia pelat beton komposit

$\mathrm{I}_{\mathrm{u}} \quad=$ Momen inersia saat kondisi uncracked

Ic $\quad=$ Momen Inersia saat kondisi cracked

$b_{e} \quad=$ Lebar efektif 
Vol. 22, No. 2, Oktober 2020

Berikut adalah potongan melintang untuk menggambarkan bagian dari pelat komposit floor deck

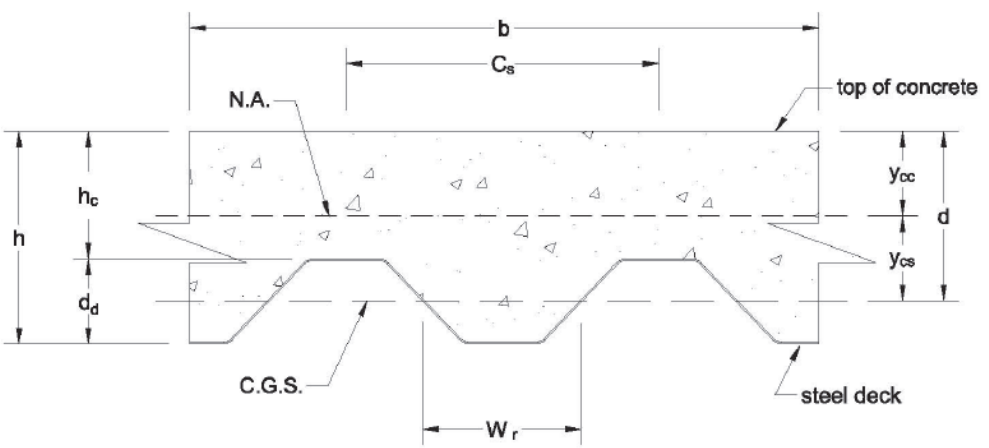

Gambar 4. Penampang pelat beton floor deck

\subsubsection{Momen Inersia pada Kondisi Crack}

Berikut merupakan persamaan momen inersia pada kondisi cracked

$$
I_{c}=\frac{b}{3 n} y_{c c}^{3}+A_{s} y_{c s}^{2}+I_{s f}
$$

dimana:

$y_{c c}=$ Jarak dari atas pelat ke garis netral dari cracked section $(\mathrm{mm})$

$y_{c s} \quad=\mathrm{d}-\mathrm{ycc}$

As $\quad=$ Luas steel deck per satuan lebar $\left(\mathrm{mm}^{2}\right)$

$\mathrm{n} \quad=$ Modular rasio $(\mathrm{Es} / \mathrm{Ec})$

$\mathrm{b} \quad=$ Lebar pelat

$I_{s f} \quad=$ Momen inersia

\subsubsection{Momen Inersia pada Kondisi Uncrack}

Berikut merupakan persamaan momen inersia pada kondisi uncracked

$$
I_{u}=\frac{b h_{c}^{3}}{12 n}+\frac{b h_{c}}{n}\left(y_{c c}-0.5 h_{c}\right)^{2}+I_{s f}+A_{s} Y_{c s}^{2}+\frac{W_{r} b d_{d}}{n C_{s}}\left[\frac{d_{d}^{2}}{12}+\left(h-y_{c c}-0.5 d_{d}\right)^{2}\right]
$$

dimana:

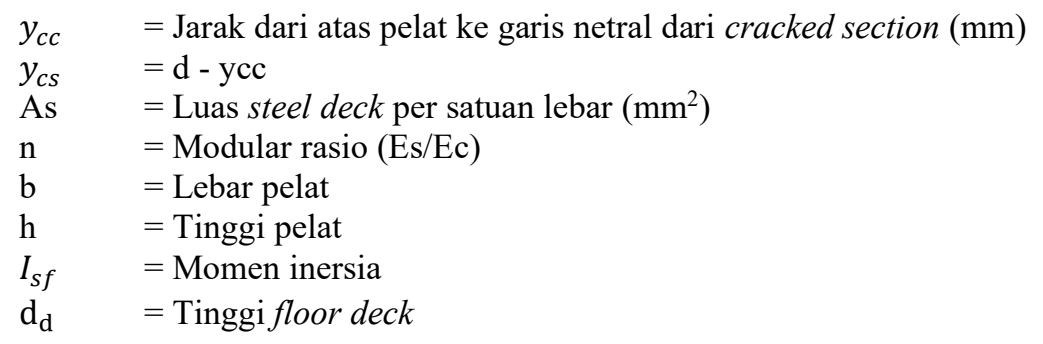

\section{HASIL DAN PEMAHASAN}

Nilai lendutan didapatkan dari sensor potensiometer yang diletakan pada tengah bentang dan $1 / 4$ bentang sisi kiri dan kanan spesimen dan dibaca oleh data logger. Nilai regangan yang terjadi didapatkan oleh pembacaan sensor strain gauge. 
Vol. 22, No. 2, Oktober 2020

\subsection{Load - Deflection Beton Komposit Floor Deck}

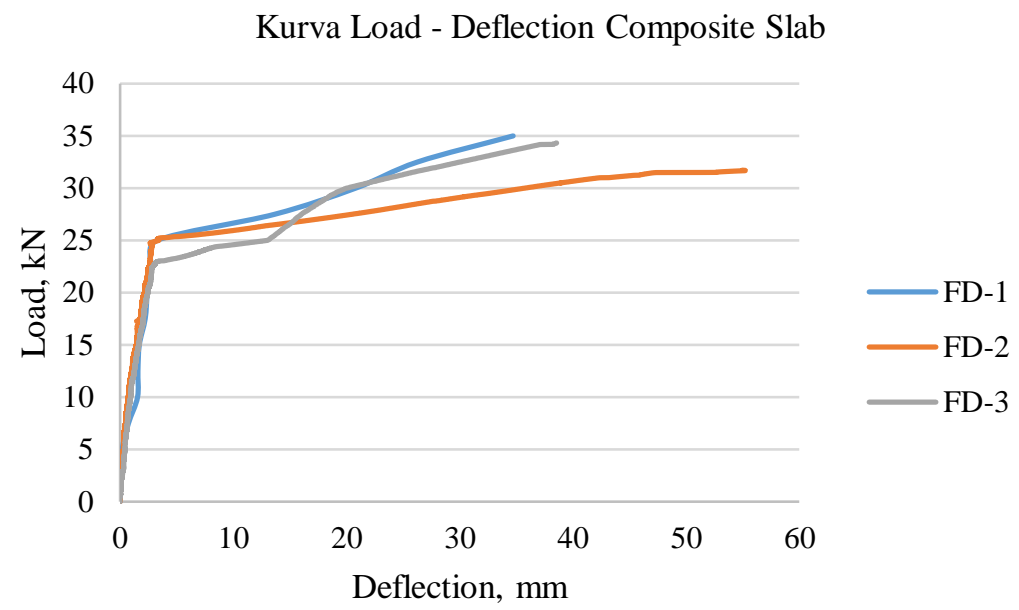

Gambar 5. Grafik lendutan pada spesimen

\subsubsection{Pelat FD-1}

Pada grafik menunjukkan besarnya lendutan akibat pembebanan monotonik sampai spesimen mengalami keruntuhan. Berdasarkan grafik tersebut menunjukkan bahwa besarnya lendutan maksimum sebesar 34,722 mm pada tengah bentang. Beban maksimum yang dapat ditahan oleh pelat sebesar $35 \mathrm{KN}$. Initial crack terjadi pada saat beban mencapai 27,5 KN. Pembebanan dihentikan ketika pelat terjadi keruntuhan dan debonding antara beton dengan floor deck sehingga didapatkan end slip sebesar $38 \mathrm{~mm}$. pada kondisi ini menandakan bahwa embossment yang terdapat pada floor deck memiliki kapasitas bonding sampai dengan $35 \mathrm{KN}$.

\subsubsection{Pelat FD-2}

Pada grafik menunjukkan besarnya lendutan akibat pembebanan monotonik sampai beban maksimum. Berdasarkan grafik tersebut menunjukkan bahwa besarnya lendutan maksimum sebesar 55,23 mm pada tengah bentang. Beban maksimum yang dapat ditahan oleh pelat sebesar $31,72 \mathrm{KN}$. Initial crack terjadi pada saat beban mencapai $24,5 \mathrm{kN}$. Pembebanan dihentikan ketika pelat mengalami keruntuhan dan tidak mampu menahan beban dengan dan terjadi debonding antara beton dengan floor deck sehingga didapatkan end slip sebesar $22 \mathrm{~mm}$. pada kondisi ini menandakan bahwa embossment yang terdapat pada floor deck memiliki kapasitas bonding sampai dengan $31,72 \mathrm{kN}$.

\subsubsection{Pelat FD-3}

Pada grafik menunjukkan besarnya lendutan akibat pembebanan monotonik sampai beban maksimum. Berdasarkan grafik tersebut menunjukkan bahwa besarnya lendutan maksimum sebesar $38,56 \mathrm{~mm}$ pada tengah bentang. Beban maksimum yang dapat ditahan oleh pelat sebesar $32,5 \mathrm{KN}$. Initial crack terjadi pada saat beban mencapai 22,5 KN. Pembebanan dihentikan ketika pelat mengalami keruntuhan dan tidak dapat menahan beban dan terjadi debonding antara beton dengan floor deck sehingga didapatkan end slip sebesar 12,89 mm. pada kondisi ini menandakan bahwa embossment yang terdapat pada floor deck memiliki kapasitas bonding sampai dengan $32,5 \mathrm{KN}$.

Tabel 1. Rekapitulasi Hasil Uji

\begin{tabular}{ccccc}
\hline No & Kode & Beban Maksimum $(\mathrm{kN})$ & Lendutan $(\mathrm{mm})$ & End Slip $(\mathrm{mm})$ \\
\hline 1 & FD-1 & 35,00 & 34,72 & 38,66 \\
2 & FD-2 & 31,72 & 31,72 & 22,37 \\
3 & FD-3 & 32,50 & 38,56 & 12,89 \\
\multicolumn{2}{c}{ Rata-rata } & 33,07 & 35 & 24,64 \\
\hline
\end{tabular}


Pelat beton komposit floor deck dapat menahan beban maksimum yang dapat ditahan oleh pelat sampai batas debonding antara floor deck dengan beton dan beton mengalami patah dengan kondisi floor deck mengalami tekuk atau buckling pada beban mencapai sebesar 33,07 kN. Lendutan maksimum yang terjadi akibat pembebanan monotonik rerata mencapai $35 \mathrm{~mm}$, pada saat crack mulai terjadi lendutan yang terjadi rerata mencapai 2,905 dimana lendutan izin yang didapatkan dari L/240 adalah 6,25 mm. Besarnya slip yang terjadi akibat pembebanan secara monotonik pada pelat beton komposit mendapatkan nilai rerata sebesar 24,64 $\mathrm{mm}$.

\subsection{Load - Deflection Beton Komposit Floor Deck}

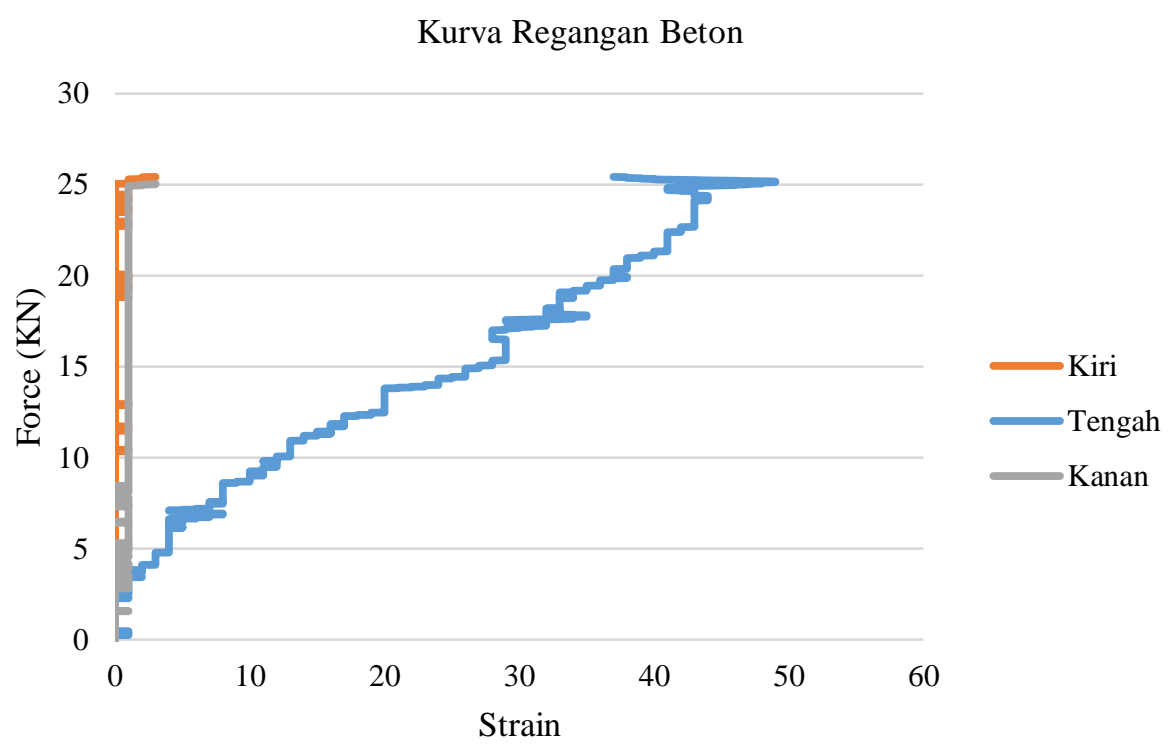

Gambar 6. Kurva regangan beton pada spesimen

Menurut SNI 2847-2019 menjelaskan bahwa regangan maksimum untuk serat tekan terjauh pada beton adalah 0,003. pada kurva terlihat bahwa regangan tarik yang terjadi pada saat adanya cracking sebesar kurang lebih 0,003 yang terbaca oleh strain gauge pada $1 / 4$ bentang kiri dan kanan. Namun, pada bagian tengah bentang kondisi regangan 0,003 terjadi pada saat pembebanan sekitar 3,7 kN dan maksimum regangan tarik pada tengah bentang mencapai 44,3 . 


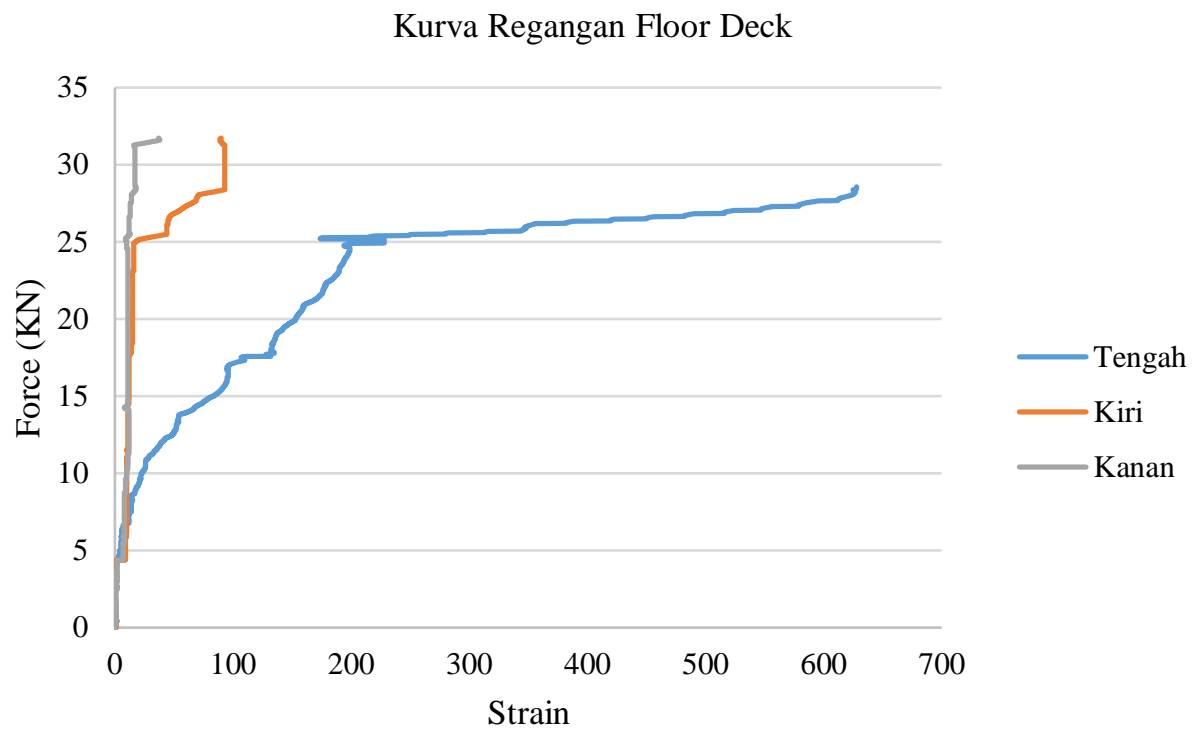

Gambar 7. Kurva regangan floor deck

Regangan yang terjadi pada floor deck diamati dengan menggunakan strain gauge eksternal yang diletakan pada tengah bentang dan $1 / 4$ bentang kiri dan kanan pelat. Nilai regangan yang terjadi terbesar pada tengah bentang dengan mencapai nilai regangan 649 pada beban mencapai $27,8 \mathrm{kN}$.

\subsection{Pola Keruntuhan Pelat Beton Komposit}

Beban optimal dicapai sebagai hasil dari pelepasan ikatan di antarmuka antara floor deck dan beton [8]. Sebelum mencapai kekuatan penuh baik beton atau baja, sering kali terjadi pembengkokan pada floor deck menyebabkan pelepasan material beton dan dek baja [9]. Mekanisme keruntuhan yang terjadi pada pelat beton komposit terjadi secara tiba-tiba. Kondisi ini sangat membahayakan jika terjadi di lapangan. Hal ini terjadi akibat tidak adanya tulangan tambahan seperti wiremesh atau pun kondisi wiremesh yang sudah karat dan tidak sesuai dengan spesifikasi yang dibutuhkan, sehingga tegangan tarik tidak sepenuhnya dibebankan pada floor deck dan mencegah terjadinya keruntuhan yang secara tiba-tiba.

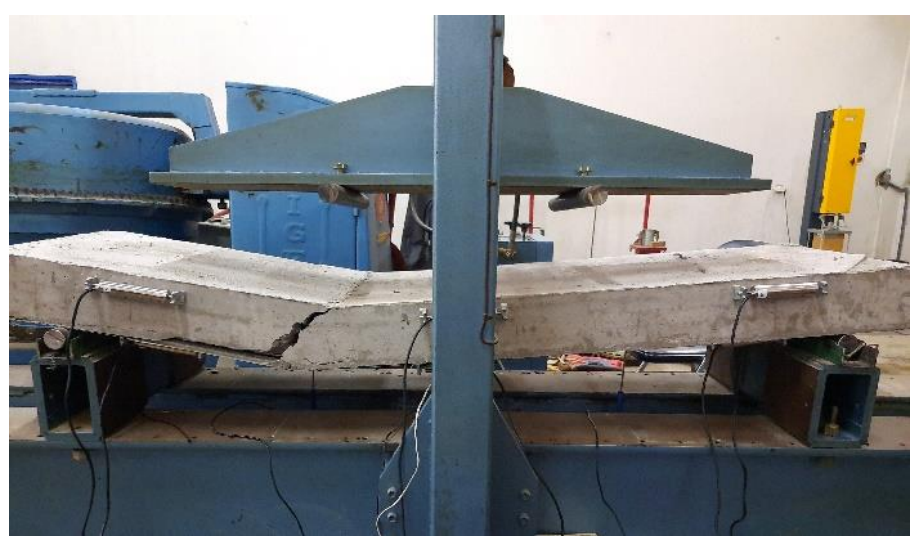

Gambar 8. Pola Keruntuhan Pelat Beton Komposit Floor Deck 
Tulangan susut pada pelat beton komposit menjadi berpengaruh terhadap daya lekat beton dengan floor deck. Pada saat proses pengeringan beton, susut yang terjadi hanya ditahan oleh embossment yang ada pada floor deck hal ini mengurangi debonding yang terjadi antara beton dengan floor deck.

Slip yang terjadi akibat pembebanan secara monotonik mulai terjadi pada pembebanan pertama dilakukan dan semakin bertambah secara signifikan sesuai dengan penambahan beban pada pelat beton komposit.

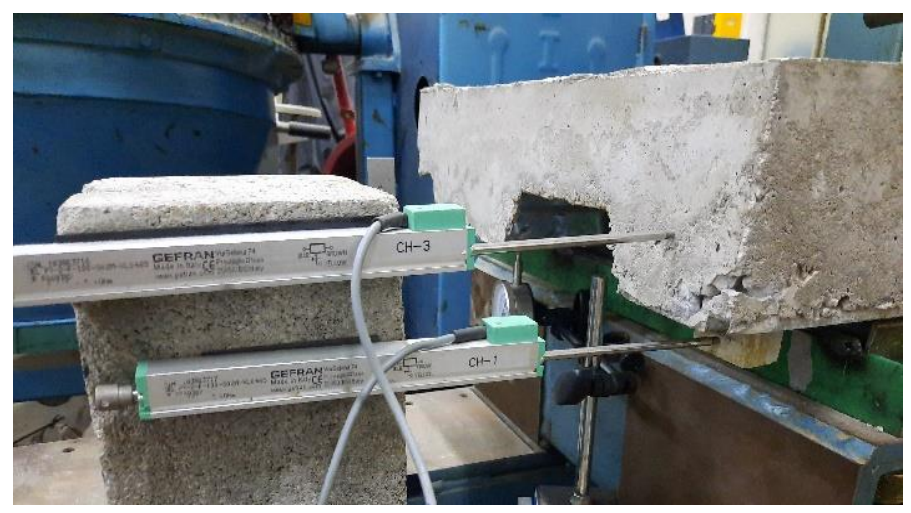

Gambar 9. Pengukuran slip pada beton dengan floor deck

Slip yang terjadi pada pelat beton komposit menggambarkan bonding yang terjadi pada beton dan floor deck akibat pembebanan. Emboss yang terdapat pada permukaan floor deck merupakan sambungan geser efektif pada saat pelat mengalami tekan dan embossment ini umum digunakan dalam pelat komposit [10]. Semakin besar beban yang diberikan pada pelat yang mengakibatkan terjadinya lendutan dan terjadinya slip antara beton dengan floor deck. Hal ini menunjukkan daya lekat yang terjadi antara beton dengan floor deck.

\section{KESIMPULAN}

Berdasaran hasil penelitian dan analisis yang telah dilakukan pada pelat beton komposit floor deck, dapat disimpulkan bahwa:

a. Pelat beton komposit floor deck memiliki kekuatan beban maksimum yang dapat ditahan oleh pelat sampai batas debonding antara floor deck dengan beton sebesar 33,07 kN. Lendutan maksimum yang terjadi akibat pembebanan monotonik rata-rata mencapai $35 \mathrm{~mm}$, pada saat crack mulai terjadi lendutan yang terjadi rata-rata mencapai 2,905 $\mathrm{mm}$ dimana lendutan izin yang didapatkan dari $\mathrm{L} / 240$ adalah $6,25 \mathrm{~mm}$.

b. Besarnya slip yang terjadi didapatkan dengan melakukan pengukuran pada ujung pelat yang mengalami slip antara beton dengan floor deck. slip yang terjadi antara beton dengan floor deck mencapai rata-rata 24,64 mm. Hal ini menggambarkan kekuatan lekatan yang diberikan oleh embossment pada floor deck terhadap beton.

c. Regangan yang terjadi pada beton saat kondisi crushing mencapai 0,003. pada tengah bentang regangan maksimum yang terjadi sebesar 0,044. Sedangkan regangan yang terjadi pada floor deck maksimum terjadi pada tengah bentang sebesar 649 dengan beban mencapai $27,8 \mathrm{kN}$.

Berdasarkan hasil analisis dan simpulan, maka diperlukan penelitian lebih lanjut yaitu dengan menambahkan variabel uji seperti penambahan angkur untuk menambah kekuatan bonding antara beton dengan floor deck, penambahan variasi diameter wiremesh dan variasi bentuk embossment. Hal ini dilakukan agar dapat membandingkan hasil satu sama lainnya. Serta perlunya pengukuran lebih lanjut mengenai slip yang terjadi berdasarkan penambahan beban sehingga dapat dilakukan analisis yang efektivitas dari bentuk embossment terhadap slip yang terjadi.

\section{UCAPAN TERIMA KASIH}

Penulis mengucapkan terima kasih atas organisasi Politeknik Negeri Bandung atas dukungan moril pada penelitian ini. Penulis juga berterima kasih kepada Yulianto Petrus Krisologus, Drs., M.M. atas diskusi dan dukungan yang bermanfaat. 


\section{DAFTAR PUSTAKA}

[1] Marimuthu, V., Seetharaman, S., Arul, S., Chellappan, A., Bandyopadhyay, T., Dutta, D. (2006). Experimental studies on composite deck slabs to determine the shear-bond characteristic $(m-k)$ values of the embossed profiled sheet. Journal of construction steel research, 63

[2] Rian Rustopo, Dewi Sulisyorini, Dimas Langga. (2017). Uji Eksperimental Kuat Lentur Pelat Bondek Beton Konvensional dengan Menggunakan Material Recycle. Fakultas Teknik. Universitas Sarjana Wiyata Tamansiswa Yogyakarta.

[3] Simon, J., Visuvasam, J., \& Babu, S. (2017). Study on shear embossments in steel-concrete composite slab. In IOP Conference Series: Materials Science and Engineering (Vol. 263, No. 3, p. 032022). IOP Publishing.

[4] Martinus Muliater, dkk. (2018). Analisis Lendutan dan Slip Pada Pelat Komposit Beton - Metal Deck Berdasarkan Perilaku Uji Statik. Konferensi Nasional Teknik Sipil 12. ISBN: 978-602-60286-1-7.

[5] Hajir Satih Abbas, dkk. (2015). Experimental Studies on Corrugated Steel - Concrete Composite Slab. Gradevinar 67 (2015) $3,223-225$.

[6] American Nastional Standard Institute/Steel Deck Institute. (2011). C-2011 Standard for Composite Steel Floor Deck-Slabs. ANSI Accredited Standard Developer.

[7] SNI 2847-2019. (2019). Persyaratan beton struktural untuk bangunan gedung. Badan Standarisasi Nasional.

[8] Kan Y C., Chel L H., Yen T. (2013). Mechanical Behaviour of Lighweight Concrete Steel Deck. Construction and Building Material.

[9] Merryfield G., El-Ragaby A and Ghrib. (2018). New Shear Connector for Open Web Steel Joint with Metal Deck and concrete slab floor system. Construction Build Mater vol. 125

[10] Mistakidis, E., Dimitriadis, K. (2008). Bending resistance of composite slabs made with thin-walled steel sheeting with indentations of embossment. Thin-walled structur. doi: http://dx.doi.org/10.1016/j.tws.2007.08.001 